\title{
The Problem of Older People Welfare from the Value Approach Perspective
}

\author{
Lubov Ivankina $^{\mathrm{a} *}$, Ekaterina Anikina ${ }^{\mathrm{b}}$ \\ * Corresponding author: Lubov Ivankina, ivankina@tpu.ru \\ ${ }^{\text {a }}$ Tomsk Polytechnic University, 30, Lenin Ave., Tomsk, 634050, Russia, ivankina@tpu.ru, +7-903-953-7182 \\ ${ }^{a}$ Tomsk Polytechnic University, 30, Lenin Ave., Tomsk, 634050, Russia, anikinaea@tpu.ru, +7-903-913-0730
}

\begin{abstract}
http://dx.doi.org/10.15405/epsbs.2016.02.58

The paper presents the situation in the modern society, which realizes the key value and strategy concerning old age - ageing in society, where the idea about opportunities and potential of a certain stage of life changes. It is proved that the dominating attitude to old age, being fixed in definite manifestations - from public opinion, social stereotypes to the political decision made, acts as a factor stimulating life satisfaction in general. The purpose of research is to change modern people's attitude to the old age value. To study the problem the research applied explication method with the help of which the main research notions - hermeneutical approach, comparative analysis method - were specified. The research resulted in the analysis of the theoretical construct of the concepts of old age and ageing, approval of the fact that old age concept fastens in public opinion the stereotypes about social expectations, having prescriptive character at the process of choosing some actions by an old person.
\end{abstract}

(C) 2016 Published by Future Academy www.FutureAcademy.org.uk

Keywords: Welfare; happy ageing; dynamic ageing; value approach to old age; adaptive-regulatory ageing model.

\section{Introduction}

The relevance of appealing to studying welfare problems from the point of view of value approach is conditioned by the fact that compensation abilities of old people are connected with turning their view of life to the emotionally meaningful relationships and the attitude of society to ageing and old age becomes a very important factor of evaluating old people's degree of life satisfaction, acting as the major indicator of subjective welfare (Cooperative meeting of experts on benchmarks and indicators of health and welfare for the politics, 2013).

Being a complicated, complex solidarity phenomenon of objective and subjective parameters of an individual's life, welfare with the help of the mechanism of dominant ideas and values is regulated by social expectations and attitude to definite social events, including the attitude to the problem of ageing. Motives, values, attitudes specify the required individually-specific coordinates significant for 
a person. It is a value-motivating factor that defines such welfare parameter as a range, which includes the factors an individual considers to be significant. At the stage of generation, welfare is connected with the concern for the informatory fullness, meaningfulness and value of life as a whole being the means of achieving personal goals (Fesenko, 2005) and as expectation of what it is necessary to strive for. Within this framework, the process of studying welfare, according to Diener\&Suh (1998), must take into account not only the welfare level, being measured, but also the inner, individual coordinates.

Ageing of a person as well as any other period of their life cycle represents a complex process including all vital levels - physical, physiological, social, economic, psychological, and moral. The key predisposition and value of age at a definite life cycle run like a common golden thread through the age.

While ageing is followed by reducing vitality of a person and changes happening in life, the people's attitude to them in this age play the role of a regulator in selecting an action. Two main approaches to ageing existed and were realized in different sociocultural systems in the previous phases of mankind development. One of them was based on the dominating respect to old age, help and support of old people, whereas another one denied the old age values and justified social disdain towards old people. In spite of the significant difference between them, both approaches consider the problems of ageing predominantly as the problem of shortage, and, consequently, the necessity of benefits, protection, support, which fixes old age as the burden for society.

The modern stage of development concerning the problem of ageing is characterized by forming a new paradigm oriented at ageing liberalizing, which reflects the conception of old age as read in conjunction with constructive and deconstructive aspects of a certain life cycle (Rogozin, 2012).

The key dichotomy of perception and formation of old people condition consisting in the escaping attitude to ageing or liberalizing from ageing, on the one hand, and in searching the inner resources of the ageing process itself or the liberalizing of ageing, on the other hand, was justified in the book "Old age" written by Vincent (2003). The author defines old age as a period of endless opportunities, whose major obstacles for realization are "stereotypes accelerated in the society, but not the natural and inevitable characters of old age" (Vincent, 2003: p. 61).

Nowadays, old people are considered by the world community as a positive factor in the process of social development. The major reason for the emphasis change became the attention of the United Nations organization paid to the problem under discussion. An issue of the journal "The Gerontologist" published in February 2015 was devoted to the problem of satisfactory ageing (Green, 2014).

Such notions as "satisfactory ageing" and "dynamic ageing" have become commonplace recently. Satisfactory ageing is defined as a preferable outcome, "which contributes to a person's ability to adapt to the growing aging changes and cope with them retaining the aim and sense of life" (The concept of successful ageing, 2012). And dynamic ageing is understood, mainly, as the situation when old people have a good health condition and stay freemen, are actively involved in their professional activities, feel more independent in their everyday life and more actively fulfill their social riles (European Year for Active Ageing and Solidarity between Generations, 2012).

What ideas preceded the new approach and what are the qualitative changes in understanding?

\section{Ideas, forming the older people's welfare}


One of the answers to the stated questions was given by the professor Z. Eitner, the leading gerontologist of Germany, who conducted the research aimed at creating the image of old age, conveyed by the method based on books for children. It turned up that the books applied the same images of old people, which reflected the burden of the years lived, grief and the detachment from the outside world (Kekukh, \& Kekukh, 2013). The given experiment enabled proving the theory that social expectations form the stereotypes influencing the attitude to the people belonging to the present age group via dominating ideas, images, ideas, and values.

Drawing special attention to the limited opportunities of ageing people contributed to domination of three sequential stages known as division of life into three parts - studying, working, and having rest in the attitudes to old age (Kohli, 1986). The third stage of life was described as the stage of dependence, decay, losses and was justified in the model of inferiority (Townsend, Godfrey, \& Denby, 2006). In the 90 s of the 20th century the changes at the labor market led to the situation when the schematic conception of life which put the completion phase to the level of having rest was replaced by the conception of dynamic ageing, aimed at encouraging the prolonged participation of old people in public life. Instead of drawing attention to what people cannot do the priority was placed to the competences and knowledge they obtain (Jacobs, 2004). The given conception was affirmed to be realized in social decisions at the end of 90 s by the World Health Organization, which contributed to the fast implementation of ideas into research and practical activities (WHO, 2002; Walker, 2006).

The notion "happy ageing" understood as satisfaction of a person with the past and present years of life was introduced in 1961 by Hevingherst (1972). The given notion fixed the theoretically justified and experimentally educed positive interrelation between the active lifestyle in the old age and satisfaction with life. Even earlier, the research of E. Erikson validated the conception of an individual's psychosocial development (Green, 2014), according to which every person goes through eight life-cycle stages and the last eighth stage solves a specific evolutionary task - rethinking about the past years and the perception of the fact of ageing. The successful stage passing results in creating the idea of life value, structural assessment of what was achieved and ability to stay productive, while the unsuccessful stage passing results are characterized by despair, assessing the achievements as the senseless valueless ones.

During the further research, Hevingherst(1972) and his colleagues concluded that old people do not differ from the middle-aged people in regard to their social and psychological peculiarities. To measure the life satisfaction of old people the following criteria were defined: mode of life, socially acceptable for this age group; activity at the level of middle age; positive self-concept and evaluation of the personal occupation; subjective feeling of happiness and life satisfaction.

Together with the conception of happy ageing the conception of successful ageing became commonplace in the 80s of the 20th century. In 1987 Rowe \&Kann (2002) published the research proving the conception of successful ageing, which outlined that successful ageing, is influenced by three factors: general physical state, high level of mental and physical activity, productive social interaction. In 2011 G. Iwamasa and M. Iwasaki introduced the model of successful ageing which included physical, social, functional and psychological health constituent element (Bryulina, 2012). 
Nowadays, the mentioned set of elements is complemented by material and spiritual aspects of life, which allows considering the model of successful ageing to be a sophisticated model.

In the old age, according to adaptive-regulatory ageing model (Frolkis, 1988), the development and strengthening of adaptive-regulatory processes aimed at surviving, increasing vitality and life expectancy happens simultaneously with the processes of age destruction and disorganization. Adaptation represents the ways of adjusting, regulation, harmonization of an individual's interaction with the environment. A human is an active subject who adapts to the environment with the accordance of the personal needs, interests, objectives and actively gains independence in consolidating the decisions. At this level, an individual is presented as a set of functions including situation perception and taking decisions; capacity for change; processes informativeness.

The concept of anti-aging called "vitauct", which occurred during the evolution along with the process of ageing was presented in $60 \mathrm{~s}-70 \mathrm{~s}$ of the 20 th century and provided the basis for a new approach to old age being the period of the continuing development stage but not the final one (Frolkis, 1988).

Not incidentally, the age over 70 is called the third youth in China. In addition, the role of the individual in regulating the stated processes increases rapidly in comparison with the previous stages of life cycle, while the development of ageing process depends on the active attitude to life, to oneself, to the actions made with the purpose of developing own organism and individuality. It is no coincidence that eudemonistic aspect of welfare, which is connected with the feeling of life meaningfulness and worthwhileness, and affective aspect of welfare, which is connected with the emotional state and feelings, as well as the way a person reacts to own life experience and achievements have existential value for an old person. Maslow (1999) without explaining the mechanisms of development insisted on the fact that every person is, to a certain degree, "own project" and creates own character and life.

The explanation of this fact is given in the theory of psychological systems (Klochko, 2008). The concept of system determination of the psychological systems theory considers the multidimensional world of a person as a complex psychological system as read in conjunction with the objective world in the part of the world mastered by this person, i.e. is important and valuable for a person. System complex represents a certain array of different objects - systems interacting with each other using a required method. However, the main emphasis is put on the difference between the quality of objects and interrelation necessary for the formation of a definite unity of the inner, subjective attitude of a person to reality, which makes the essence of what is characterized as our life.

In this se of qualities welfare is the idea of how it should be i.e. the concept of something ideal, something achieved in reality, and the difference between the given images, is, as we suppose, the idea of welfare. It is possible to state that the idea of welfare is somewhere between the ideal and real, which can be fixed by means of value approach, generating from the definite social standard. Thus, the world outlook and value guide lines determine the growing tendency to the increase or decrease of satisfaction with life during the terminating life cycle period.

\section{Conclusion}


Public need in new paradigm and value-conscious guides appears when the previous value system does not meet the requirements of the changed historical reality. The major value system being the alternative to the old one is capable of not only rebuilding the system of moral values but also changing the degree of their motivational influence. New paradigms concerning ageing change the priorities in the attitude to old age as to the period of living the last years and form the constructive, optimistic ground for the life which continuous dynamically but not ceases by means of the changed perception.

Thus, the realization of modern valuable consideration of the problem of ageing as a continuing life, making the idea of happy ageing contribute to the increasing welfare via the suggested samples of ageing and old age, following which a person chooses the activities oriented at the happy ageing and, as a result, causing the decrease of life satisfaction.

\section{Acknowledgements}

This work was performed by the authors in collaboration with Tomsk Polytechnic University within the project in Evaluation and enhancement of social, economic and emotional wellbeing of older adults under the Agreement No.14.Z50.31.0029.

\section{References}

Fesenko, P. (2005). What is psychological welfare? Brief review of main concepts, 46, 35-48. Moscow: MosGU Publ. (in Russian)

Cooperative meeting of experts on benchmarks and indicators of health and welfare for the politics. (2013). Health-2020. Copenhagen, Denmark, 5-7 February 2013. World Health Organization.www.euro.who.int/ data/assets/pdf file/0005/197312/e96819r.pdf.

Diner, E.\&Suh, M. (1998). Subjective well-being and age: An international analysis. Annual Review of Gerontology \& Geriatrics, 17, 304, 324.

Rogozin, D. (2012). Five books about old age liberalizing.Psychology of maturity and ageing, 4, 59-66. www.sociologos.ru/novosti/Obzor_sociologicheskoj_literatury_ot_Dmitriya_Rogozina. (in Russian)

Vincent, J. (2003). Old age. London: Routledge.

Green, O. (2014). Ageing for a good cause. The news from the heading "Health, relevant information, a news discussion at Newsland".hw.net.ua/starost-vo-blago-novost-iz-rybriki-zdorove-aktyalnaia-informaciiaobsyjdenie-novosti-diskyssii-na-newsland. (in Russian)

The concept of successful ageing. (2012). www.vechayamolodost.ru/pages/teoriistarenija/koncuspstad61.html. (in Russian)

European Year for Active Ageing and Solidarity between Generations. (2012). europa.eu/ey2012/ey2012main.jsp?catId=971\&langдId=en.

Kekukh, I. \&Kekukh, N. (2013). Dynamic ageing: from the concept to reality. Gomel: Bark. (in Russian)

Kohli, M. (1986). The world we forgot: a historical review of the life course. In V. W. Marshall (Ed.), Later Life: The social psychology of aging, Beverly Hills: Sage, 271-303.

Townsend, J., Godfrey, M.\&Denby, T. (2006). Heroines, villains and victims: older people's perceptions of others. Ageing \& Society, 26(6), 883-900.

Jacobs, T. (2004). Slotbeschouwingen. 'Actiefouderworden' en 'autonomie': twee kernbegrippenvoor het ouderenbeleid? In T. Jacobs, L. Vanderleyden\& L. Vanden Boer (Eds.), Op latereleeftijd: de leefsituatie van 55-plussers in Vlaanderen, Antwerpen-Apeldoorn: Garant, 329-342.

WHO (2002). Active ageing. A policy framework, a contribution of the World Health Organization to the second United Nations world assembly on ageing. Madrid: Author.

Walker, A. (2006). Active ageing in employment: Its meaning and potential. Asia Pacific Review, 13(1), 78-93.

Havigherst, R. (1972). Developmental Tasks and Education, 3rd ed. New York: David McKay Co.

Rowe, J.\&Kann, R. (2002). Successful aging: a concept analysis. Journal of Theory Construction and Testing, December 22.

Bryulina, E. (2012).Old age - route continuation.Site the psychology country. Section: applied psychologist.psyhelp.rodim.ru/vozrast/starost-put.html. (in Russian)

Frolkis, V. (1988).Aging and Life-Prolonging Processes. Leningrad: Science. (in Russian)

Maslow, A. (1999). New boundaries of human nature. Moscow: Sense. (in Russian)

Klochko, V. (2008). Postnonclassical science and the problem of explanation in psychology. Methodology and the history of psychology, 1, 165-78. (in Russian) 